Metodički obzori 6(2011)2

Original scientific article

UDK: 372.878:004

Received: 1. 11. 2010.

\title{
MOTIVATION AND LEARNING RESULTS IN MUSIC EDUCATION RELATED TO BLENDED LEARNING
}

\author{
Bogdana Borota, PhD, Assistant prof. \\ University of Primorska, Faculty of Education Koper (Slovenia) \\ e-mail: bogdana.borota@pef.upr.si
}

\begin{abstract}
Computerised environment is a learning environment which is often used in primary schools. The specifics of teaching and learning supported by computers are particularly interesting from the point of view of research into blended learning. Blended learning means combining various methods as well as teaching and learning modalities and also combining classical learning with computerised environment learning. In the newly created system of learning environments it is a challenge to recognise and understand connections between motivation, learning results and learning performance.

Our contribution deals with the research which took place at musical classes in the third grade of primary school. The experimental group implemented besides classical didactic materials for class learning also the interactive computerised environment Musical Image Format, Rhythm. The results have shown a motivation for learning in the computerised environment and statistically significant higher results achieved by the experimental group in the areas of musical rhythm and metrum.

Key words: music in primary schools, information-communication technology, blended learning, learning environment, learning motivation, musical image format, musical rhythm
\end{abstract}

\section{Introduction}

Learning environment is an important factor of successful education. Today computer learning environment is quite often used. Researches have shown that the use of computers in music classes seems less common (Gerlič, 2005; Cencič, Cotič, Medved Udovič, Borota, 2009). We have therefore been even more closely following the achievements which indicate positive trends and effects of the use of modern technology for music in the Slovenian primary schools.

Recently, scientists have been studying not only the influences of encouraging learning environments but, above all, the influences of learning in diversified learning environments. We speak about the so called blended learning where the following elements are combined or composed into a whole: (1) various modalities of teaching and learning, (2) different methods of teaching and (3) different learning environments as for example computer environment and traditional classroom environment (Bonk, 2006). 
In the newly established system of learning environments, it is a challenge for teachers to recognise and understand connections between motivation, learning results and learning performance. Namely, there is a certain interactive relationship between learning and motivation, since motivation influences learning and learning brings changes to motivation (Rotar Pance, 2006; Juriševič 2006).

In this article we are going to address learning of music in the computer environment Musical Image Format, Rhythm, which was, in terms of blended learning, introduced as one of a number of learning environments into the musical instruction in the $3^{\text {rd }}$ grade of primary school. Our main interest was addressed to identify the motivation of pupils for learning in the computer environment and establish whether the pupils of experimental group who where involved in the blended learning achieved better results in the area of listening, performing, reading and notating musical rhythm. As it is important to study and understand the afore mentioned areas in the context of the research, in our introductory chapter Musical Image Format, Rhythm we will present the formation and implementation of a computer environment and certain contents which are related to interactive learning and various learning modalities.

\section{Musical Image Format, Rhythm}

The computer environment Musical Image Format, Rhythm was established in cooperation with lecturers and students of the Faculty of Education Koper, Univerza na Primorskem (University of Littoral) accessible at: http://iktglasba.pef. upr.si (Borota, Brodnik, 2007). ${ }^{1}$ The creation and the implementation of computer environment Musical Image Format, Rhythm have both been based on the idea of a microword which enables connection with and deepening of the experiences of real and virtual world (Papert, 1993). For setting up the new computer learning environment for music we referred to the basic principles of how information-communication learning environments function and enable constructivist paradigms of learning and teaching. Such learning environments have to enable the user with the following:

- focus of the attention on the selected problem/artistic challenge;

- use of intuitive thinking for understanding new learning contents;

- simple learning and clarity of work;

- repeated cycle of learning underpinning the learning from experiences based on experiments and mistakes;

- creativity and individual construction of knowledge with exercises which have different solutions (Papert, 1993).

The above mentioned principles could be recognised already through the visual conception of the user interface (Picture 1). The latter is in all teaching units conceived equally. The unified concept ensures an effective teaching transfer both at the level of computer usage and at the level of musical knowledge transfer (Davidson, 1990).

\footnotetext{
${ }^{1}$ Random visitors should fill in the following user name: demo and password: demo.
} 
Picture 1: Graphic interface of the teaching unit My composition

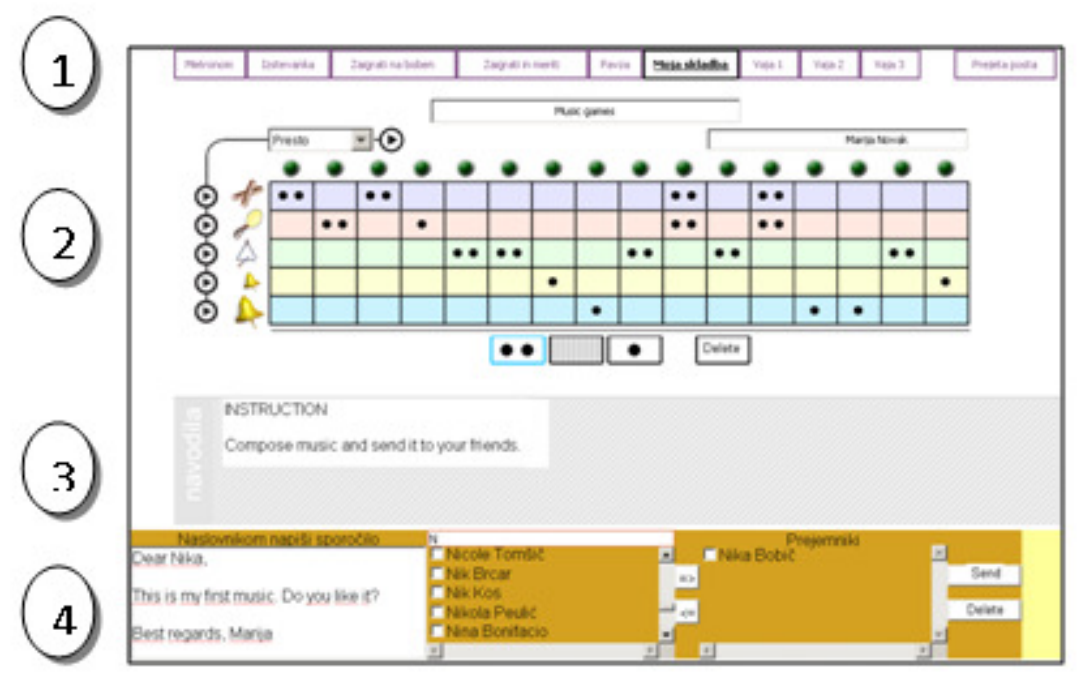

The graphic interface consists of: (1) menu of learning units, (2) working space, (3) learning instructions and (4) virtual environment. The elements of graphic interface are equally arranged in all teaching units that we can select by clicking on tabs in the menu in the upper part of the window. The unified structure of working space ensures a faster and more effective redirection of pupils' attention and interaction from computer to teaching contents.

Teaching contents are related to listening and differentiating as well as reading and notating musical rhythm. The latter is done through a multi-sense perception of musical tempo and metrum. The essential advantage of learning in an established computer environment is in the direct experience of interactive connection between picture image (visual perception) and sound (audio perception) image of music. As it is a question of early stage of music literacy we took into account also the findings of experts on the importance of development related use of both teaching language and music symbol recording system that pupils use for their independent learning in the computer environment (MacGregor, 1992).

In the primary schools reading and notating music is a component of music literacy taking place gradually from image and symbolic to musical notation. The American psychologist Jeanne Bamberger divided, on the basis of the studies on the development of early music literacy with the help of image notation, the latter into two phases: figurative phase of graphic presentation (ranging symbols one next to the other) and the phase of metric representation (also the number of sounds and duration are expressed in symbols), (Bamberger, 2000). We took into consideration all those findings when creating the image notation system by which pupils notated rhythm in the established computer environment and created one ore multi-sound rhythmic compositions. Here, we developed the image notation at the level of metric phase of graphic presentation of musical rhythm which enables differentiation in the perception of relationship between length of beat and division (Borota, 2010). 
Picture 2: Development of image symbols for rhythm notation in computer environment Musical Image Format, Rhythm

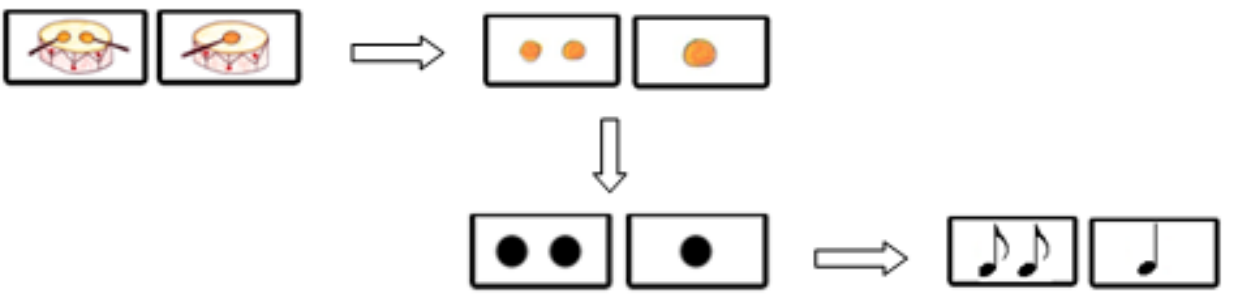

Picture 3: Notation of five tone rhythmical composition in computer environment Musical Image Format, Rhythm

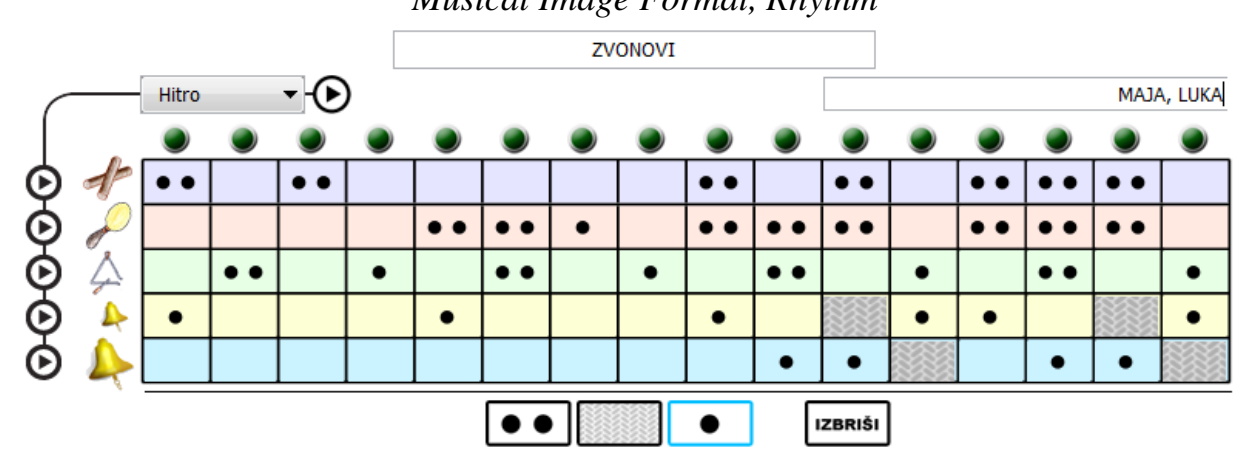

Picture 4: Transcript of the composition Bells (Picture 3) in music notation

The artistic outlook of symbols develops through learning units from concrete to symbolic which ensures an effective transfer from image to musical notation (Picture 2). We paid a lot of attention to the formatting of symbols since, in terms of development, an adequately formatted symbol helps pupils to recognize information and to establish connections between sound and artistic image of music. Symbols function in music composition as a kind of construction material by which pupils compose various sound patterns. Ms. Bamberg (2000) has ascertained that pattern composing and de-composing is an important way of learning, based on researching, looking for and verifying solutions for problem conceived tasks.

In order to have a better audio image of the composition Bells (Picture 3) readers are offered a transcript from the image to music notation (Picture 4). 


\section{Bells}

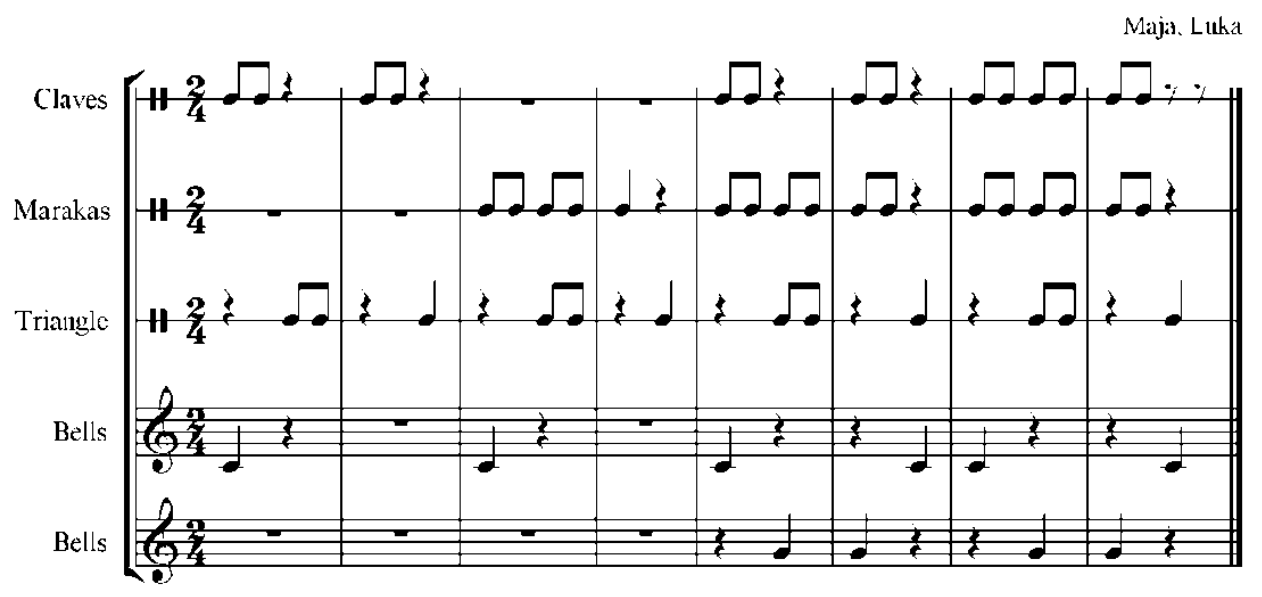

The graphic image of the working area in the computer environment (Picture 3) has all the elements of a musical score. The interaction with the computer programme ensures immediate sound information on the notated. We can at the same time listen to one, two or more parts. This computer programme function is significant since pupils usually improve their composition of music and their product by listening to the performance. The notated composition can be sent via internet connections. Here, both the picture and the sound image are saved. The opportunities of participating in a virtual community can be used for group and cooperative learning.

We can save all pupils' products in the mail box. As they are marked with date and comments they can serve teachers as documentary materials on the progress and musical development of each pupil separately. From the composition notation teachers are able to recognise the level of musical syntax development which is a significant indicator of musical development.

\section{Motivation for learning in computer environment Musical Image Format, Rhythm}

Education is a complex process where motivation is an important variable. Why is it good in the new learning situations to monitor, besides cognitive aspects, also the motivational aspects of learning? Experts claim that in this way we understand better the concepts pupils established in the new learning situations (Juriševič, 2006). Based on that, teachers can much more easily create new models of teaching.

The German psychologist Rheinberg and his team defined relations between motivation, learning processes and learning achievements. According to Rheinberg, the influence of motivation is evident at three levels:

- in duration and frequency of learning activities (time of active learning);

- in the form of executing learning activities (regulating learning efforts of pupils, the will to learn, using specific strategies to reach goals); 
- in the functional mood of pupils during learning activities (excitement, general psychological state of pupils during learning (Rheinberg, 2000, in: Juriševič, 2006, pg. $18)$.

It is even more important to study motivation in the context of learning in the computer environment because pupils find themselves in the situation when their learning performance largely depends on their motivation and their capability of independent planning of adequate learning strategies (Roblyer, 2004; Borota, 2009). And exactly because of these findings we have to take into account individual needs of pupils when learning in the computer environment (Juriševič, 2008).

Within the process model of the research we monitored the following motivation factors: interest, attractiveness and difficulty of learning. The research was carried out within a period of seven months. In the context of the study of the example, the method of self-assessment was implemented. Pupils assessed feelings, eagerness and interest with the help of a 3-level scale. Three class level teachers and forty pupils from the third grade of the nine-year primary school participated in the research, twenty three boys $(57.5 \%)$ and seventeen girls $(42.5 \%)$.

We analysed twenty learning situations where computer environment Musical Image Format, Rhythm was implemented. Based on the results of the analysis we established a very high percentage $(88.2 \%)$ of learning contents and learning process understanding, interesting and undisturbed learning, adequate time planning as well as good feelings and functional atmosphere for pupils during their learning. All these findings are an important attribute of inner motivation (Rheinberg 1997). Teachers interpreted the above mentioned findings as the result of gradual introduction of computers into the music instruction and from the point of view of development as a result of adequate planning of learning.

It is also necessary to study the interest for music in each individual learning context separately (Järvelä, Niermivirta, 2001). Namely, learning motivation (for music) can be significantly different in reference to learning environment since it may be influenced by individually conditioned factors of relationships between teaching and learning environment (Volet, 2001). Someone may love singing and playing the instruments, but have no interest to work on computer and vice versa. On the contrary, pupils with less developed performance skills can much more easily articulate their musical abilities with the help of modern technology. This might be an important element to encourage learning interest (Rudolph et al., 2005).

We also wanted to know in our research what the most enjoyable part for pupils during their work on computers was. We summarized our findings into the categories of individual motivational incentives (Juriševič, 2008). The results have shown that at first the situational interest which was encouraged in pupils by mere novelties (listening to music by headphones, selecting by mouse clicking, successful computer planning, printing the notated) was in the forefront. Also individual interest (selecting music contents, composing music, team learning) as well as self-regulation and independent learning (independent learning with the help of written instructions, learning by personal ideas and plans, selecting learning environments and learning contents) were well expressed throughout the entire period of research. Pupils also liked the fact that learning was simple and that they were successful in learning. Among positive motivational incentives they also mentioned the interactive learning which was the most 
distinctive in the case of creating image recording in connection with sound testing and in verifying and changing musical notation (Borota, 2009).

From the notes of teachers' reflections we found out that there was a positive productive pupils' motivation which was expressed in their selection of more demanding tasks and in their perseverance in improving achievements and their desire to put in place new musical ideas. Pupils of the first three grades of primary school were particularly susceptible to those incentives, as the critical period of productivity motivation development is exactly between the third and eighth year of age (Heckhaus, v Marentič Požarnik, 2000; Rotar Pance, 2006). In general, pupils estimated that computer aided learning is much more fun and relaxing, than »classical learning « in the classroom (Borota, 2009).

\section{Research on pupils' music achievements in blended learning}

The research had been conceived as a pedagogical innovation which was supposed to contribute to the development of school practice in the area of music teaching in the third grade of primary schools. The main principle of the innovation was based on verifying combinations of various methods and modalities of teaching and learning in relation to combining different learning environments. The main difference between the control and the experimental group was in the fact that pupils of the experimental group, besides musical performance in the classroom and their work with textbook, learned also by using a computer environment.

The teachers of the experimental group combined various teaching environments so that pupils, when mastering new conceptual knowledge and developing skills, verified their understanding and deepened their experiences during the same teaching lesson in various ways and in different environments. Their instruction was also problem oriented where experts and scientists have found out positive connections between the problem conceived teaching and cognition capabilities and their thinking (Cotič, Felda, 2006).

The connecting elements between different learning environments were the teaching objective and in the area of didactic materials the objective was the musical notation. The implemented image symbols were the same in workbooks and in computer environment as well as in different didactic materials such as for example plates and cards with symbols. The meaning of the symbol remained always the same. It had equal informative contents in different learning environments. Only the methods and the modalities of learning were different. The education and music literacy took place in phases which are significant for learning of music: listening, performing, reading and notating (Gordon, 1997; Sloboda, 2007).

In our study we set the following general research hypothesis: Computer environment learning will have a positive impact on pupils' results in the area of rhythmic skills and knowledge.

In the empirical research we implemented the experimental method of pedagogical research with certain elements of action researching. We used the onefactor experiment with school grades as comparative groups. The research was carried 
our in seven moths and 136 pupils participated in it, 65 in the experimental and 71 in the control group. Prior to the research the experimental and the control group of pupils were not statistically significantly different in the categories of perception of metrum, performing rhythmic accompaniments, image recording of rhythmic motives, image recording of tone and pause duration as well as in the categories of rhythm performance after the image recording. Data were collected according to a 5-level assessment list of music abilities, skills and knowledge as well as with the help of partially structured interviews with pupils and teachers who used the established computer environment during their instruction. Besides that, we analysed teaching preparations, reflections and materials produced during the monitoring of the instruction.

The research is important from the point of view of developing teaching and learning models which would to a larger extent enable development of elementary music abilities for which the critical development period ends roughly at the age of nine (Gordon, 1997). In the area of rhythmic abilities the perception and performance of rhythm is important while it helps us hear and feel all other dimensions of musical rhythm (Bamberger, 2000). And for the rhythm performance it is essential to master the relationship between the length of beat and division, where the basis is the feeling of music beat and cadence as the fundamental metric unit (Gordon, 1997; Sloboda, 2007).

The research results have shown that the experimental group achieved statistically significant higher results in all the above mentioned areas.

Pupils included in blended learning, compared to the control group which did not use computers, achieved higher results in metrum perception $(\mathrm{t}=6,933, \mathrm{df}=134$, sig. $=0,000)$ as well as in performance of beat $(\mathrm{t}=8,389, \mathrm{df}=134, \mathrm{sig}=0,000)$. Pupils who trained their perception with the help of computers were also more successful in metrum perception in different music speed and performed it more successfully through movement. Blended learning also had an impact on better results in group music performance $(\mathrm{t}=7,852, \mathrm{df}=134$, sig=0,000), in rhythmic expression of texts $(\mathrm{t}=8,424$, $\mathrm{df}=134$, sig $=0,000)$ and in performance of rhythm $(\mathrm{t}=6,729, \mathrm{df}=134$, sig=0,000). In all the categories pupils of experimental group achieved higher average values. Their results are on the outside expressed also in harmonious musical performance, accurate expression of rhythmic texts and count-outs as well as in performance of metrum and rhythm in common tempo.

We ascertained our general hypothesis that learning in computer environment had a positive impact on pupils' results in the area of rhythmic knowledge and skills. We can, in terms of concrete research study, indirectly confirm the positive impact of blended learning on learning motivation and educational achievements of pupils. 
Table 1: Results of the t-test in the area of the perception and performance of metrum and in the performance of rhythm in relation to the pupils of experimental and control group

\begin{tabular}{|c|c|c|c|c|c|c|c|c|c|}
\hline \multirow[b]{2}{*}{$\begin{array}{l}\text { Assessment } \\
\text { Categories }\end{array}$} & \multirow[b]{2}{*}{ 苛 } & \multirow[b]{2}{*}{$\mathrm{N}$} & \multirow[b]{2}{*}{ Mean } & \multirow{2}{*}{ 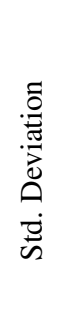 } & \multicolumn{2}{|c|}{$\begin{array}{c}\text { Levene's Test } \\
\text { for Equality of } \\
\text { Variances }\end{array}$} & \multicolumn{3}{|c|}{$\begin{array}{l}\text { t-test for Equality of } \\
\text { Means }\end{array}$} \\
\hline & & & & & $\mathrm{F}$ & Sig. & $\mathrm{t}$ & $\mathrm{df}$ & 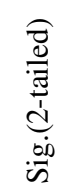 \\
\hline \multirow{2}{*}{$\begin{array}{l}\text { Music beat } \\
\text { perception }\end{array}$} & Exp. & 65 & 3,34 & ,713 & \multirow{2}{*}{,143 } & \multirow{2}{*}{,706 } & \multirow{2}{*}{6,933} & \multirow{2}{*}{134} & \multirow{2}{*}{,000 } \\
\hline & Con. & 71 & 2,46 & ,753 & & & & & \\
\hline \multirow{2}{*}{$\begin{array}{l}\text { Music beat } \\
\text { performance }\end{array}$} & Exp. & 65 & 3,31 & ,705 & \multirow{2}{*}{,302 } & \multirow{2}{*}{, 584} & \multirow{2}{*}{8,389} & \multirow{2}{*}{134} & \multirow{2}{*}{,000 } \\
\hline & Con. & 71 & 2,21 & ,809 & & & & & \\
\hline \multirow{2}{*}{$\begin{array}{l}\text { Performance } \\
\text { in common } \\
\text { tempo }\end{array}$} & Exp. & 65 & 3,34 & ,691 & \multirow[b]{2}{*}{, 784} & \multirow[b]{2}{*}{, 377} & \multirow[b]{2}{*}{7,852} & \multirow[b]{2}{*}{134} & \multirow[b]{2}{*}{, 000} \\
\hline & Con. & 71 & 2,45 & ,628 & & & & & \\
\hline \multirow{2}{*}{$\begin{array}{l}\text { Rhythmic } \\
\text { expression of } \\
\text { texts }\end{array}$} & Exp. & 65 & 3,49 & ,664 & \multirow[b]{2}{*}{, 381} & \multirow[b]{2}{*}{, 538} & \multirow[b]{2}{*}{8,424} & \multirow[b]{2}{*}{134} & \multirow[b]{2}{*}{, 000} \\
\hline & Con. & 71 & 2,49 & ,715 & & & & & \\
\hline \multirow{2}{*}{$\begin{array}{l}\text { Rhythm } \\
\text { performance }\end{array}$} & Exp. & 65 & 3,25 & ,771 & \multirow{2}{*}{,036 } & \multirow{2}{*}{, 851} & \multirow{2}{*}{6,729} & \multirow{2}{*}{134} & \multirow{2}{*}{, 000} \\
\hline & Con. & 71 & 2,35 & ,776 & & & & & \\
\hline
\end{tabular}

\section{Conclusions}

Introduction of blended learning into the music education represents a relative novelty in the Slovenian Primary Schools. By combining different learning environments within the same teaching lesson we compose a reasonable unit of different methods and modalities of teaching and learning. The described approach seems particularly appropriate in early musical literacy, where we speak about the establishment of relationship between sound image and audio perception as well as between the picture image of music and visual perception. Of course, these connections are not simple at all; it is necessary, taking into account various modalities, to ensure also the conditions for a successful teaching transfer.

The interactive information-communication environment Musical Image Format, Rhythm was in our research study one of the teaching environments for the implementation of blended learning. Computer environment raised pupils' interest and readiness for learning and had at the same time a positive influence on their educational results in the area of perception and performance of musical rhythm and metrum. On the basis of the results of the experimental research in the third grade of primary school we have found out that the multi-mode perception of metrum (pupils can hear and see metrum in the form of light signals and perform it while listening and following the notation) has a positive impact on, both, the audio perception and recognition of metrum in different tempos, as well as on the development of skills in performance of rhythm 
and metrum in common tempo during playing on rhythmic musical instruments and during rhythmic expression of texts.

Foreign experts have also underlined the need for well developed elementary rhythmic abilities when they ascertained that feeling of metrical order is important, since it is the basis for metric hierarchies which can be recognised in children when performing three levels of metrum: as the performance of beat or meter, as performance of basic beat or tactus and its beat division. We comprehend those relations intuitively in an encouraging music environment and thus express them when we sing or play on instruments.

The above findings mentioned in our article are supposed to encourage teachers to reconsider the significance of both the diversity of methods and modalities of learning as well as the importance of multi-sense perception of musical elements, particularly in connection with early musical literacy. We would wish that the afore mentioned findings were a challenge for teachers to develop new approaches to learning and teaching music which would be based on reasonable combining of different methods and modalities into a unified learning situation in which various learning environments would intertwine and complement each other in order to spread and deepen musical experiences.

\section{Bibliography} Press.

Bamberger, J. (2000): Developing Musical Intuitions. New York, Oxford: Oxford University

Bonk, C. J., (et al.) (2006): The Hadbook of Blended Learning. Global Perspectives, Local Designs. San Francisco, Pfeiffer.

Borota, B. (2008): Vloga informacijsko-komunikacijskega okolja Glasbeni slikovni zapis, Ritem pri pouku glasbene vzgoje. V: Medved Udovič, V. (ur.), Cotič, M. (ur.), Cencič, M. (ur.): Sodobne strategije učenja in poučevanja. Koper. Pedagoška fakulteta.

Borota, B. (2009): Motivacija za učenje v računalniškem okolju Glasbeni slikovni zapis, Ritem. V: Medved Udovič, V. (ur.), Cotič, M. (ur.), Cencič, M. (ur.): Pouk v družbi znanja. Koper, Pedagoška fakulteta.

Borota, B. (2010) The Impact of Learning in the Innovative Computer Environment Musical Image Format, Rhythm on Musical Achivements. In: Valenčič Zuljan, M. (ed.), Vogrinc, J. (ed.): Facilitating Effective Student Learning through Teacher Research And Innovation. Ljubljana: Faculty of Education

Borota, B., \& Brodnik, A. (2007) Glasbeni slikovni zapis, Ritem. Retrieved April 2, 2007, from http://iktglasba.pef.upr.si.

Cencič, M., Cotič, M., Medved Udovič, V. \& Borota, B. (2009) Comparison of the usage of ICT among some compulsory subjects in the Slovenian primary schools. Problems of Education in the 21 st century, 17 (1) pp. 39-48.

Cotič, M., Felda, D. (2006): Faze reševanja matematičnega problema. V: Medved Udovič, V. (ur.), Cotič, M. (ur.), Felda, D. (ur.): Zgodnje učenje in poučevanje otrok1. Koper, Pedagoška fakulteta.

Davidson, L. (1990): Tools and environments for musical creativity. Musica Educators Journal, 76, 47-51.

Gerlič, I. (2005). Stanje in trendi uporabe informacijske tehnologije (IKT) v slovenskih osnovnih šolah. Retrieved April 10, 2010 from: http://www.pfmb.uni-mb.si/raziskave/os2005 
Gordon, E. (1997): A music learning theory for newborn and young children. Chicago, GIA Publications.

Järvelä, S., Niermivirta, M. (2001). Motivation in context: Challenges and Possibillities in Studying the Role of Motivation in New Pedagogical Cultures. In: Volet, S., Järvelä, S. (2001): Motivation in learning context. Theoretical advances and methodological implications (104-128).

Juriševič, M. (2006): Učna motivacija in razlike med učenci. Ljubljana, Pedagoška fakulteta.

Juriševič, M. (2008): Pomen (pre)poznavanja motivacijskih vzorcev učencev za uspešno poučevanje. 8. dnevi slovenskih psihologov, Bled, 18. - 19. 4. 2008, dostopno na: http://www2.arnes.si/ dpsih/aktualno1.htm, 9. 10. 2008.

MacGregor, R. C. (1992): Learning theories and the design of music compositional sofrware for the young learner. International Journal of Music Education, 20, 18-26.

Marentič Požarnik B. (2000): Psihologija učenja in pouka. Ljubljana, DZS. Books.

Papert, S. (1993): Mindstorms: Children, computers and powerful ideas. New York: Basic

Roblyer, M. D. (2004): Integrating Educational Technology into Teaching. Columbus, Marrill Prentice Hall

Rotar Pance B. (2006): Motivacija - ključ h glasbi. Nova Gorica: Educa.

Rudolph, T. E., Richmond, F., Mash, D., Webster, P., Bauer, W. I., Walls, K. (2005). Technology Strategies for Music Education. Wyncote. TI:ME.

Sloboda, J. A. (2007). The Musical Mind. The Cognitive PSychology of Music (16 ${ }^{\text {th }}$ ed.). Oxford, Oxford University Press.

Metodički obzori 6(2011)2 Izvorni znanstveni rad UDK: 372.878:004

Primljeno: 1. 11.2010.

\title{
MOTIVACIJA IN UČNI DOSEŽKI PRI GLASBENI VZGOJI V POVEZAVI Z MEŠANIM UČENJEM
}

\author{
Dr. sc. Bogdana Borota, docent \\ Univerzitet na Primorskom, \\ Pedagoški fakultet Kopar (Slovenija) \\ e-mail: bogdana.borota@pef.upr.si
}

\section{I zvle č e k}

Računalniško okolje je učno okolje, ki ga pogosto uporabljamo pri pouku v osnovni šoli. Posebnosti učenja in poučevanj ob pomoči računalnika so še posebej zanimive z vidika raziskovanja mešanega učenja (angl. blended learning). Pri mešanem učenju gre za kombiniranje različnih metod in modalitet učenja in poučevanja ter za kombiniranje klasičnega učenja $\mathrm{z}$ učenjem $\mathrm{v}$ računalniškem okolju. V novo nastalem sistemu učnih okolij je izziv prepoznati in razumeti povezave med motivacijo, učnimi dosežki in uspešnostjo učenja.

Prispevek obravnava raziskavo, ki je bila izvedena pri pouku glasbe, $v$ tretjem razredu osnovne šole. V eksperimentalni skupini se je poleg klasičnih didaktičnih sredstev pri učenju v razredu uporabljalo tudi interaktivno računalniško okolje Glasbeni slikovni zapis, Ritem. Rezultati kažejo na motiviranost za učenje v računalniškem 
okolju ter na statistično pomembno višje rezultate, ki so jih učenci eksperimentalne skupine dosegli na področjih glasbenega ritma in metruma.

Ključne besede: glasba $v$ osnovni šoli, informacijsko-komunikacijska tehnologija, mešano učenje, učno okolje, motivacija za učenje, slikovni zapis glasbe, glasbeni ritem

\section{MOTIVACIJA I NASTAVNA DOSTIGNUĆA KOD MUZIČKOG ODGOJA U VEZI S MIJEŠANIM UČENJEM}

\section{Sažetak}

Računalna je okolina nastavna okolina koju često primjenjujemo kod nastave $\mathrm{u}$ osnovnoj školi. Osobitosti su učenja i nastave pomoću računala još posebice zanimljive iz vidika istraživanja učenja u raznolikim nastavnim okolinama koje se povezuju u sisteme nastavnih okolina. Govorimo o tzv. miješanom učenju (engl. blended learning) kod kojeg kombiniramo odnosno slažemo u cjelinu: (1) različite modalitete učenja $\mathrm{i}$ nastave, (2) različite metode nastave te (3) različite nastavne okoline kao što su npr. računalna okolina i klasična nastavna okolina u razredu.

U novonastalom sistemu nastavnih okolina za učitelja je izazov da u nastavnim situacijama prepozna i razumije veze između motivacije, nastavnih dostignuća i uspješnosti učenja. Između učenja se i motivacije naime uspostavlja interaktivan odnos jer motivacija utječe na učenje, a učenje unosi promjene u motivaciju.

U izlaganju obrađujemo eksperimentalno istraživanje koje je bilo sprovedeno kod nastave muzike, u trećem razredu osnovne škole. U eksperimentalnoj se skupini pored klasičnih didaktičkih sredstava kod nastave u razredu koristila i interaktivna računalna okolina Muzički slikovni zapis, Ritam. Znači, iz vidika smo miješanog učenja kombinirali klasičnu nastavu u razredu sa samostalnim i kooperativnim učenjem u računalnoj okolini. Pošto je potrebno istraživanje i čimbenike utjecanja razumjeti u kontekstu, u nastavku predstavljamo neke značajke primijenjene računalne okoline koju smo razvili u sudjelovanju s učiteljima i studentima, na Pedagoškom fakultetu Kopar, Univerzitetu na Primorskom.

Osnivanje računalne okoline temelji na konstruktivističkim paradigmama učenja i nastave koja učeniku omogućava da: usmjeri pozornost na odabrani problem i kod toga primijeni intuitivno mišljenje; stvaralački konstruira vlastita znanja uz zadatke koji imaju različita rješenja te da primijeni ponavljajući se ciklus učenja koji podupire iskustveno učenje na osnovu pokušaja i pogrešaka. Pošto spomenutu računalnu okolinu primjenjujemo kod ranog muzičkog opismenjivanja, uzeli smo u obzir i spoznaje stručnjaka o potrebi za razvojno primjerenu primjenu nastavnog jezika i muzičkog simboličkog zapisivačkog sistema također. Muzički ritam čitamo i pišemo pomoću muzičkog slikovnog zapisa. Grafički je posrednik sastavljen od četiri dijela: menua nastavnih jedinica, radne/nastavne okoline, uputa za samostalno učenje i prostora za sudjelovanje u virtualnoj zajednici. Struktura je grafičkog posrednika kod svih nastavnih jedinica jednaka.

Istraživanje je bilo osnovano kao pedagoška inovacija. Glavni je princip inovacije temeljio na ispitivanju kombinacija različitih metoda i modaliteta učenja $i$ nastave $\mathrm{u}$ vezi s kombiniranjem različitih nastavnih okolina $\mathrm{u}$ istom nastavnom satu. Bitna je razlika između kontrolne i eksperimentalne skupine bila u strategijama učenja i nastave. Učenici su eksperimentalne skupine pored muzičkog izvođenja u razredu i rada s udžbenikom učili i u računalnoj okolini. Istraživanje je teklo sedam mjeseci, u njemu su sudjelovale četiri učiteljice razredne nastave i 136 učenika (65 u eksperimentalnoj i $71 \mathrm{u}$ kontrolnoj skupini). 
Istraživanje je važno iz vidika razvijanja modela učenja i nastave koji bi u većoj mjeri omogućavali razvoj elementarnih muzičkih sposobnosti kojih kritičko razdoblje razvoja završava od prilike kod devet godina. Na području ritmičkih sposobnosti važno je u većoj mjeri razvijati sposobnosti primjećivanja i jednakomjernog izvođenja metruma na osnovu kojih čujemo i osjećamo sve ostale dimenzije muzičkog ritma. Kod izvođenja je ritma bitnog značenja savladavanje odnosa između dobi i dijeljenja.

Rezultati su istraživanja pokazali da je eksperimentalna skupina postigla statističko važne više rezultate na svim prije spomenutim područjima. Dostignuća su se učenika pokazala u sukladnom muzičkom izvođenju, preciznom izricanju ritmičkih tekstova i brojalica te jednakomjernom izvođenju metruma i ritma. Možemo ustvrditi pozitivan utjecaj nastave u računalnoj okolini na motivaciju za učenje te pozitivan utjecaj miješanog učenja na nastavna postignuća učenika na području muzičkog ritma i metruma.

Ključne riječi: muzika u osnovnoj školi, informacijsko-komunikacijska tehnologija, miješano učenje, nastavna okolina, motivacija za učenje, slikovni zapis muzike, muzički ritam 